Original Article

\title{
The Religious and Spiritual Dimensions of Bowen Family Therapy
}

\author{
Özlem Acar Bulut ${ }^{1 \mathbb{D}}$ \\ Ministry of National Education
}

1 Psychological Counseling Specialist, Ministry of National Education, Ataşehir, İstanbul, TURKEY. E-mail: ozlemacarpdr@gmail.com

\begin{abstract}
The topic of spirituality stands out in recent years as being heavily addressed in the field of psychological counseling and guidance. A similar picture also stands out when looked at from the angle of family therapies. When looking at studies made in the field of family therapy, studies addressing the aspect of family spirituality are seen to continue increasing. Bowen's Family Systems Theory is one of these approaches. Bowen Family Theory handles the family as a system and attempts to solve the individuals' problems by considering the environment within which they are found. The individual's surroundings contain many situations, from family to culture, siblings to religious beliefs, from traditions to customs, and from relationships to spirituality. According to Bowen, spirituality is the reflection of the topic of God in relationships, and located foremost within the theory, a spiritual aspect is found in all important concepts, including ego differentiation and triangulations. Encountering religious and spiritual elements is possible in many of the concepts of Bowen Family Systems. This study handles the perspective of spirituality in the Bowen Family Systems Theory as one of the theories of family systems and the place of spirituality within Bowen Family Systems. In this context, first the Bowen Family Systems Theory is briefly introduced, then the study attempts to explain the spiritual dimension of the theory in light of some of its basic concepts. In addition, the Bowen approach is addressed from the Islamic perspective, and a case sample has been presented related to the intervention methods that can be used in this situation.
\end{abstract} Keywords: Family Systems, Bowen, Spirituality, Religious Dimension, Triangulation, Ego Diff erentiation

\section{Bowen Aile Terapisi'nin Dini ve Manevi Boyutu}

Corresponding author:

Özlem Acar Bulut

E-mail:

ozlemacarpdr@gmail.com

eISSN: $2458-9675$

Received Revision:

16.11.2019

Revision:

18.01.2020

Accepted:

10.02.2020

CC Copyright 2020

by Author(s)

\section{Öz}

Son yıllarda maneviyat konusunun psikolojik danışma ve rehberlik alanında yoğun bir șekilde ele alındığı göze çarpmaktadır. Aile terapileri açısından bakıldığında da benzer bir tablo karşımıza çıkmaktadır. Aile terapisi alanında yapılan çalışmalara bakıldığında ailenin manevi yönünü ele alan çalışmaların artarak devam ettiği görülmektedir. Bowen Aile Sistemleri Teorisi bu yaklaşımlardan biridir. Bowen Aile Teorisi aileyi bir sistem olarak ele alır ve bireyin problemlerini içinde bulunduğu çevreyi göz önüne alarak çözümlemeye çalıșır. Bireyin bu çevresi aileden, kültüre, kardeşlerden dini inançlara, gelenek göreneklere, ilişkilerden maneviyata kadar birçok durumu içinde barındırır. Bowen'a göre maneviyat Tanrı konusunun ilișkilerdeki yansımasıdır ve teori içinde yer alan başta benlik farklılaşması ve üçgenlemeler olmak üzere tüm önemli kavramlarda manevi bir yön bulunmaktadır. Bowen Aile Sistemlerinin birçok kavramında dini ve manevi ögelere rastlamak mümkündür. Bu çalışmada Aile sistemleri kuramlarından biri olan Bowen Aile Sistemleri Teorisi'nin maneviyata bakış açısı ve maneviyatın Bowen Aile Sistemlerindeki yeri ele alınmıştır. Bu çerçevede öncelikle Bowen Aile Sistemleri Teorisi kısaca tanıtılmış, ardından kuramın temel kavramları doğrultusunda teorisinin manevi boyutu açıklanmaya çalışılmıștır. Ayrıca Bowen yaklaşımı İslami açıdan ele alınmış ve bu durumda kullanılabilecek müdahale yöntemleri ile ilgili de bir vaka örneği sunulmuştur.

Anahtar Kelimeler: Aile Sistemleri, Bowen, Maneviyat, Dini Boyut, Üçgenleme, Benlik Farklılaşması

Citation: Acar-Bulut, Ö. (2020). The religious and spiritual dimensions of Bowen family therapy. Spiritual Psychology and Counseling, 5, 65 - 85. https://dx.doi.org/10.37898/spc.2020.5.1.098 
Individuals come to the world as part of a family. Throughout their lives, everything about life is learned within the family where they are born. The family's culture, life philosophy, perspective on life, religious beliefs, and spirituality are transferred to the new generations. Because of the important role family has in an individual's life, addressing one's surroundings together with the family is important while assessing the individual.

Spirituality and faith occur within parts of the family system and have an important place in individuals' lives. Spirituality appears in many places, from the individuals daily routines up to their coping methods. When addressing the family system together with spirituality from this perspective, the two can be said to be intertwined. Spiritual values, like many things learned from the family here in an individual's life, are also learned from the family and taught to the next generations. From this perspective, addressing the two concepts together, which hold such a significant place in the life of the individual, and looking at family systems in terms of spirituality are important. When looking at the literature, the number of studies addressing spirituality in family systems stands out as being quite limited (Acar \& Voltan-Acar, 2013; Asamarai et al., 2006; Berensen, 1990; Butler \& Harper 1994; Daneshpour, 2017; Jensen \& Min, 2003. This situation is also valid for the Bowen Family Systems approach, as it is one that addresses family systems. The number of studies that have looked at the Bowen approach in terms of spirituality and religion is quite small. The lack of studies related to the approach of this system's ability to be addressed in many ways in terms of spirituality forms the starting point of the current study. This study has been performed with the aim of addressing the dimension of spirituality in the Bowen Family Systems approach within the framework of the theory's basic concepts. The study is thought to fill the gap present in the related literature and to contribute to future research.

Most people are born, grow up, and develop within a family system. Individuals get support from their family throughout their lives and are support for other family members. Approaches that address family systems handle the individual's problems by starting off from this point of view (Corey, 2008). Many approaches are found within family systems theories. The Bowen Family Therapy approach is also one of these theories.

Murray Bowen's (1966) family systems therapy, also known as multi-generational family therapy, is an approach that addresses the functioning of family systems comprehensively. Bowen's theory is a clinical model that differs from psychoanalytical theories and practices. Bowen and his colleagues brought the family system to the focal point of therapy by developing an innovative perspective while working with patients with schizophrenia (Corey, 2008). Bowen (1985) advocated that values, belief systems, patterns of behavior, and anxieties are a system with an emotional dimension that conveyed over at least three generations from one to another. By utilizing generalizations about the theory (Varol, 2015), the basic principles of Bowen Family Therapy can be listed as follows: 
- The family is a whole that consists of systems that are interconnected or dependent on one another.

- The path to understanding the individual is by understanding the family system within which the individual is found.

- Each individual, being part of a system, is connected with the others.

- The individuals in the system affect one another.

The family patterns that are conveyed from generation to generation hold an important position in Bowen's family systems theory. According to this theory, when the relationship patterns occurring in the family infrastructure are understood and changed in a way that will not constitute an issue, the problems one experiences with the family disappear. In order to be able to understand the family in the best way in Bowen's approach, at least three generations of the family need to be assessed because the relationship structure is experienced as a pre-existing condition in the family dynamics and carries the personality traits of the family members from the previous generations (Corey, 2008). In this sense, Bowen Family Therapy emerged as a theory that conveys upon the traces of the past. This emphasis that Bowen Family Theory makes on the relationship patterns from the past constitutes the psychoanalytical side of the theory. Yet in the therapy process, by benefitting from the power of what has happened in the past over what is being experienced now does not just predict what change will take place; the here and now is also believed to have quite a significant place in the change. The therapist both focuses on the family's past an cares about today (Gladding, 2012).

Another important point of Bowen Family Systems Therapy is anxiety. Here anxiety sources from life and is emotional and physical. The intensity of this anxiety, which is also experienced within the family, differs from person to person. In order to soothe and eliminate the anxiety experienced in the family, one needs to utilize the family patterns. Bowen advocated that either excessive closeness or distance causes anxiety by affecting the family relationships. The anxiety level the family experiences is measured through the reactions they generally give to stress and their sensitivity to the special issues conveyed from generation to generation; anxiety is conveyed from the previous generations to the later ones (Bowen, 1966).

When considering the reactions family members give when facing relationship problems, the reactions given to these emotional problems can cause chronic anxiety. Family therapy should attempt to decrease the chronic anxiety experienced as an assistant in reaching awareness of family members' emotional systems and increase the level of differentiation in order to emphasize self-transformation instead of changing others (Kerr \& Bowen, 1988). 
Differentiation levels also emerge in individual relationships with God. According to Bowen, spirituality is the issue of God reflected in relationships. As such, teaching about God and spirituality in a unique way can help resolve the systems that take place within the family. Mankind's relationship with God starts with the divine, continues and develops through stages of differentiation, and proceeds towards a reintegration where God is understood in terms of the relationship. This concept of God, beyond both the traditionally religious view of God outside the ego as well as the psychological view of God as the ego has vital importance for understanding healthy human and family relations (Berensen, 1990). Because of the style of approach in evaluating concern and anxiety in the family, its handling of the level of family differentiation, the various intervention techniques offered in this direction, and the intertwined history and interconnected family dynamics, Bowen Family Systems Theory is a significant model that can be used for working with spiritual and religious families (Daneshpour, 2017).

\section{The Basic Concepts of Bowen Family Therapy}

Bowen Family Therapy has eight basic concepts that are used for the purpose of describing the anxiety experienced within the family and the family's emotional processes related logically and linked to other concepts within the self. These concepts are: differentiation of self, triangles/triangulations, the nuclear family's emotional system, multigenerational transmission process, family projection process, emotional cut-off), sibling position, and societal regression (Goldenberg \& Goldenberg, 2008). Bowen Family Systems Theory by nature also contains a spiritual dimension. In this sense, considering the spiritual aspects is also important when addressing these concepts. Aside from these concepts, the concept of religious inquiry, which has a spiritual aspect in the Bowen approach, will also be addressed under this heading in the scope of the study. Information related to detailed descriptions of these concepts and their spiritual dimensions is given below.

\section{The Spiritual Dimension of Differentiation of Self}

The concept of differentiation of self is one of the most important in Bowen Family Systems Theory (Polat, 2014). Aside from awareness of one's emotions and thoughts, differentiation is maintaining existence independent of others (Corey, 2008). According to Bowen (1985), differentiation of self is "The psychologically distinction of the self from the internal intellectual and emotional systems, and as a result, the simultaneous distinction and freeing of the self from the family's origins and other individuals within the social structures to which one is linked." Meanwhile, differentiation is the ability to work independently in personal choices while still being emotionally connected through the concentration of important relationships in the family system (Kerr \& Bowen, 1988). 
The level of differentiation between spouses in the family has an important place in developing family functions. While the developmental levels of nuclear family functions are low for couples and families with low levels of differentiation, the tendencies to develop nuclear family functions is at a higher level for couples with high levels of differentiation (Klever, 2009). Self-differentiated individuals are under no one's influence while making choices, have a strong sense of self, and see themselves as valuable (Kerr \& Bowen, 1988). Alongside this, self-distinguished individuals are aware of themself, can recognize their feelings and thoughts, take responsibility for their choices, and abide by these choices (Kesici et al., 2014).

Differentiation has two dimensions: the individual's ability to emotionally and cognitively distinguish the self from the family and the ability to distinguish one's own emotional cognitive processes from one another (Bowen, 1978). The first dimension is the balance of unity and individuality. Individuals at the highest level regarding differentiation both maintain their own individuality and establish flexible relationships with others (Klever, 2009). These individuals possess the ability to distinguish feelings and thoughts from one another, don't allow their emotions to get in the way of their logic, have a clear stance, and easily tolerate and adapt to changes (Goldenberg \& Goldenberg, 2008). In the second dimension, individuals with low levels of differentiation cannot distinguish real life from their feelings, make decisions with their emotions and implement these decisions, block their cognitive abilities due to their excitement, and are vulnerable. All these cause individuals like this to remain in dilemmas within the family (Kerr \& Bowen, 1988).

The spiritual individual is connected with the sacred and with what is transcendental, and this aspect distinguishes it from other concepts (Koenig, 2012). Spirituality expresses the faith related to the presence of a transcendental reality beyond the physical existence that is generally seen (Wortinghon et al., 1996). Spirituality is a concept often confused with religiousness. Religion is generally addressed as an inclusive concept and has a close relationship with spirituality (Zinbauer \& Pargament, 2013). Religion is a method in which spirituality can be expressed where individuals come together in line with specific beliefs and has a sectarian dimension (Young, Wiggins-Frame, \& Cashwell, 2007). While religiousness is often addressed at the level of social or group analysis, spirituality occurs at a more individual level, and this is the point that distinguishes it from religion. Spirituality and individuality are relatable to differentiating the self, which is based on keeping logic in the foreground when making decisions and choices in the dimension of differentiating the thoughts and emotions of the individual (Mert \& Topal, 2018). Spirituality involves great deep change throughout the human developmental process, and many ways exist for conceptualizing this change or maturation process, which comes to mean spiritual development. When addressing differentiation as a precursor of the holistic 
perspective, greater differentiation is considered to bring more spiritual maturity (Rizkallah \& Hudson, 2019).

Differentiation in the spiritual dimension of self-differentiation is seen to have positive or negative impacts on spiritual orientations. Individuals with high levels of differentiation have high spirituality, and individuals with low levels of differentiation have low spirituality. In addition, the relationship between individualism and spiritual orientation has a negative aspect. In other words, those who are too individualistic have low spiritual orientations (Mert \& Topal, 2018). Barbel and Horing (1999) emphasized the differentiation of self in healthy personality development to positively impact spiritual, psychological, and physical health. Accordingly, one's spirituality contributes to one's differentiation. While differentiation of self impacts one's spirituality, this also contributes to the individual's holistic health.

Bowen stated that evaluating the differentiation levels of each family member depends on many factors, such as individual stress levels, how each individual reacts to various stressors, and the frequency of interactions an individual has with extended family members. A hypothetical differentiation exists for a person who can resolve the emotional bond with the family and can see functioning easily without emotional fusion in the family system. The process of differentiation lasts all life long, and individuals don't always differentiate. When looking at this issue from a spiritual or religious perspective, families in traditional cultures, especially Islamicoriented lifestyles, are seen to have highly intertwined ancestral relational dynamics and many families take responsibility for problems in the extended family. In this respect, teaching how to differentiate from one another while maintaining bonds with family members can be extremely useful and can change may functional interaction networks (Danesphour, 2017).

\section{The Spiritual Dimension of Triangulation}

Triangulation is the smallest, most basic relationship form in Bowen Family Systems Theory, and triangulations have a key role in making sense of Bowen Theory. Triangulations are the dynamic balance in a three-person system. Triangulation occurs when, in order to reduce the anxiety between two people and the pressure or tension that results from this anxiety, a third person becomes involved in the relationship (Kerr \& Bowen, 1988). Triangulation is used much more as a way of dealing with the anxiety in the family and has an important place in family therapy (Acar \& VoltanAcar, 2013). A fixed structure and social environment are located at the base of the triangle. The triangle is the building block of the family's emotional system and is the smallest, fixed, and stationary interaction system. As long as the triangle remains constant, the two-person system also remains constant. However, if anxiety arises, someone from outside enters the family to form the triangle. This person exposes 
the tension by entering into conflict with the family (Bowen, 1976). Although the presence of a third person is acceptable in a healthy triangulation where each one is inter-related, the emotional dimension of the triangulation perceives the third person as a source causing boundaries to be violated. This situation creates anxiety and distress for each sub-system in the family (Minuchin, 1981).

Bowen presented his theory where families who possess more differentiation use triangulation as the way for dealing with anxiety within the system. Differentiation is a process that involves interpersonal and personal capacities (Kerr \& Bowen, 1988). In contrast, triangulation is the example of a potentially disruptive relationship. The process of managing relational anxiety involves a third person in the process for preventing conflict; triangulation may become dysfunctional when it involves minimizing responsibility and placing people against one another. For example, parents can triangulate a child in order to change the focus of conflict in their marriage relationship. This also can have the shape of a parent-child coalition against the other parent. For example, if the father is very strict, a mother-child coalition can form. Triangulation is a response to anxiety in the system. Therefore, while triangulation reflects the lack of differentiation within the individuals and the system, it also inhibits the differentiation that occurs in all or part of the system formations. As such, in the clinical context, a large part of the therapist's attention is focused on helping clients remove themselves from the triangulations within their relationships; the therapist simultaneously self monitors for ways to be able to become included in a type of triangulation in the therapeutic relationship. Differentiating functions develop by having the client gain awareness with regard to the client's anxiety of how it manages the system. The client then finds concrete ways on how to be able to establish different relationships with each person in the system and is encouraged to use these ways. Many times, the different ways of establishing relationships with the various people in the system cannot be realized until the client calms down or their anxiety is soothed; this situation forces the client to reluctantly establish non-reactive relationships (Bowen, 1966).

Despite generally being accepted as dysfunctional within relationships, some triangulations can serve productive purposes. Triangulation may also occur in religious couples who see God as a member of their own relationship. As a different member of the relational system, God has been able to be considered as an aid in studies on couples' marriage conflicts and problems. The destructive triangular relationship in the God-couple relationship emerges when God is blamed, chosen as a side in a fight, or used to relieve the couple's pain. This situation later on causes the conflict process the couple is found in to continue uninterruptedly. Here, however, incorporating a third person into the system can be functional as an assistive role in managing the anxiety the couple is experiencing (Rootes et al., 2009). In fact, Butler 
et al., (2002) revealed that the god triangulation in the relationship of a couple can be a basic support that is able to have important contributions in the relationship. For example, according to Butler et al. (2002), establishing a relationship with God through prayer facilitates resolving conflicts in the couple's relationship. As a dimension of the god triangulation in the couple's relationship, prayer is a ritual that unites the differentiation and allows for more interpersonal differentiation by developing relational functions.

Additionally, in the parent-child coalition where they are afflicted with abuse, triangulation helps the family member who is a victim of violence, and thus allows the severity of abuse to be reduced. Even in such a chaotic environment, this method can provide the sense of a safe place for family members who have been exposed to abuse. Although this situation does not eliminate the devastating effect the child has witnessed between the mother and father, it does no harm to the mother-child coalition because the problem is about the exploiter's abuse of power and the structure of inequality rather than the lack of the mother's level of differentiation (Kerr \& Bowen, 1978).

The following can be said when looking at triangulations from the perspective of Christianity: Christians have such a strong sense of belonging and meaning toward marriage that they regard marriage as "sacred" (Sheen 2004). Christian traditions regarding marriage involve the couple promising to stay connected to each other for life before society and God, so even if the marriage has problems, marriage still has religious and moral significance for them. Couples who experience problems in their marriage generally use triangulation as a means of managing conflict and anxiety (Minuchin, 1981). This situation is also valid for Christian couples. Triangulation in marriages arises in order to eliminate the problem in the couple's relationship without resolving it or in order to avoid conflict (Butler \& Harper 1994). Triangulation damages the boundaries that separate marriage from other structures. Although defining boundaries is important for the therapist of any couple, if the therapist wants to include the triangulation of God in the marriage, the couple's religious values and thoughts need to be given importance (R1zkallah \& Hudson, 2019).

Triangulation can also appear between the client, therapist, and God. God and the self-relationship can have an important position in the client's problems. The therapist wants the God-and-client relationship to be interconnected positively, emotionally, and intensely interrelated. Clients' certainty of their stance on God is important for the therapy process (Jensen \& Min, 2003).

\section{Religious Queries in Bowenian Family Systems}

The religious quest is an individual's state of expression and living oriented toward the sacred. The quest contains the characteristics of "the mature concept of religion," 
and signifies the dimension of "open-ended, existential questions." The religious quest has been suggested to reflect a mature and developed spiritual understanding. As a religious quest, spirituality involves being open to facing existential questions, accepting the complexity and uncertainty of life, constantly feeling doubt about unknown facts, and tolerating temporary understandings. The extent to which religion and spirituality are intertwined or the degree to which they are independent of one another is constantly being debated. As mentioned in the previous sections, spirituality and religion sometimes intertwine, and sometimes are far removed from one another. Spirituality is sometimes connected with traditions, and sometimes is independent of them. Even in this situation, the issue is a query. Questioning is a part of human development and maturation. Questioning is seen to increase when faced with a traumatic situation (Batson \& Ventis, 1982).

Genia's (1996) study detected a positive relationship between anxiety and religious conflict with questioning. According to this, individuals who are in more of a quest have lower self-confidence and higher susceptibility to depression. If considering the fact that querying itself will cause anxiety, internal questioning can allow one to experience an tolerate this anxiety; in this way one can initiate change. Contrary to internal querying, anxiety-focused questioning reveals itself by being doubtful or interrogative. These doubts do not permit transformation and plunge one into a dead end. The result of decreased triangulation together with drops occurring in differentiation functions can increase religious inquiry. This has two bases: the first contains optimal human development, openness to experiences, resistance to pain, and healthy boundaries. Self-differentiation involves the doubts felt towards the spiritual and religious and conditionally also has the ability to both lighten and face anxieties. Similarly, interpersonal differentiation in the family of origin should allow the necessary space and support for one to discover one's spirituality. The second basis embodies spirituality maturity and taking charge. Accordingly, the functions of differentiation are related to the measure of spiritual maturity. Because taking charge can be considered as a measure of spiritual maturity, the function of differentiation is expected to be related to increased inquiry, at least in the form of a self-initiated quest (Jankowski \& Vaughn, 2009).

The greater the intergenerational triangulation is, the more spiritual inquiry also increases. Triangulations bring together more existential questioning. This situation is seen more when the individual experiences moderate triangulation. In other words, while high-level inquiry can have an overwhelming and intense effect on one's efforts at differentiating, low-level inquiry can show the need for differentiation to be less when existential inquiry is used as a means for doing this. Religious inquiry has a multi-dimensional structure and has relationships with many functions in the family. Whether or not religious research has been done deliberately and whether or not change in the family dynamics has occurred as a result of the inquiries is important 
in terms of determining the nature of the queries. Queries often focus on seeing triangulation as an answer to developing adults' self-defining behaviors (Rootes et al., 2010). Querying can also have a variety of functions in the family. If we are to give an example, querying can allow the individual to earn their place in the family. Despite having a self-perspective that opposes the family structure, individuals in this way are able to feel belonging with a family that lets them see themselves still related to the family, a family that chooses for itself. Here, having a relationship with the self or being related to others at the same time as being unique and different on one's own comes across as a situation identical to Bowen's concept of differentiation. This decision may be a conscious and sincere decision that one gives or it may be given through obligations arising from other relationships. In both cases, this situation causes the individual to mature (Burris et al., 1996).

Existential questioning reaches its highest level when triangulation is at a medium level. While questioning increases with increased existential concerns within the family system, decreased questioning occurs with lower levels of anxiety. When looked at in terms of religious questioning, mid-level triangulation can be representative of family systems that try to find balance when met with a young adult who is questioning a new spiritual or existential entry arising in the family or in one's own life. Parental triangulation can be viewed as an answer given by the family system to the steps the developing adult throws out while in the face of this one's attempts to separate from the system. As a result, querying is the result of an adult's effort to differentiate (Rootes et al., 2010).

\section{The Emotional System in the Nuclear Family}

The most important point in the concept of the nuclear family's emotional system is evaluating the individual within the emotional system of the family in which they grew up and focusing on the individual's past experiences and the current moment. This concept is an intergenerational concept (Acar \& Voltan-Acar, 2013). The family system has an important place in determining the individual's emotions, behaviors, thoughts, and symptoms. For this reason, individuals should be evaluated with the family in which they are found, because as individuals are impacted by the emotional system of the nuclear family within which they are raised through the intergenerational transfer process, they gain specific behavior patterns and transfer these patterns to their current family. According to Bowen Family Theory, individuals are argued to affect their marriages and other relationships by what they bring from their own families, and this effect reflects itself onto their own families, children, and new generations. According to this, the best way to solve individuals' current problems is to change the patterns of dysfunctional interactions that are brought from their own family. Thus other family members can also change (Goldenberg \& Goldenberg, 2008). 
Three different situations arise as a result of intense intertwining that occurs between couples: emotional or physical disorder in one of the spouses, chronic and unresolved marital conflict, and one or more of the children suffering psychologically (Kerr \& Bowen, 1988). When a spouse suffers emotionally or physically and this somehow manifests itself, the anxiety this spouse experiences is felt by all other family members. Chronic and unresolved marital conflict is seen to go back and forth between emotional distance and emotional intimacy. Sudden fluctuations are found between positive and negative emotions. When the emotional distance is intense, the emotions in the family atmosphere are negative, and when emotional closeness is intense, positive feelings dominate the family environment. Anxiety that forms in the family is experienced by the spouses. When one or more than one child suffers psychologically, the parents pay attention to the child/children, and the low level of differentiation they have is reflected onto the children. Anxiety that forms in the family is reflected by the child/children (Goldenberg \& Goldenberg, 2008).

In an undifferentiated relationship, each spouse communicates with the other's relational qualities and wants to comply with these. For this reason, a model can appear wherein the role of each spouse takes place on three points. Bowen defined this fusion as the equivalent of the spouses' transference (Kerr \& Bowen, 1988). For example, an extremely responsible and very social Muslim man wants to establish a relationship with an obedient woman who doesn't work and relies on him for everything. While no problem exists in the early relationship, this situation becomes a relationship between a controlling man and a desperate woman who provides no contribution emotionally to the relationship. Here both sides also have the same level of differentiation because they express themselves by identifying with the other party. However, emotional symptoms appearing within the woman is an expected situation because she makes too many attempts to maintain balance in the relationship. Moreover, she becomes polarized as a person who works inadequately and becomes prone to showing signs of helplessness, such as the chronic pain, depression, or psychotic symptoms that are often seen between Muslim couples. Symptoms can also appear in men who are extremely functional within the relationship because the man in this case is at the same time firmly situated in an effort to conduct tasks properly for the other family members (Danesphour, 2017).

\section{Emotional Rupturing}

Emotional ruptures are a result of emotional rigidity. When intense relationships that source from tolerating others too much makes the individual uncomfortable or causes anxiety, the individual reacts to this situation by moving away from emotions. The behavioral indicators of emotional rupture may be self-isolation, physical separation from others, or depression (Titelman, 2003). On the other hand, people 
with high differentiation can remain physically separated from others in order to increase their own autonomy; this situation brings honest and strong communication together (Sauerheber et al., 2014).

Bowen made a clear distinction between "leaving" the family and "growing up." Growing up is accepted as an aspect of healthy differentiation. While this shows effort on the issue of reaching the goals adults set and has one maintaining experiences independently, at the same time, this means they continue to see themselves as part of the family systems. Rupture (in the sense of breaking apart from the family) is a statement in the form of one of the family members leaving the family by deciding to differentiate clearly from the family background. Ruptures can help alleviate the tension that emerges in the family but is not enough for changing the relationship forms in intense relations; the processes in these relationships proceed repeatedly and raise tensions (Kerr \& Bowen, 1988). These are important concepts that need to be researched in Muslim families because these concepts are a way of defining values and expressing the intensity of the closeness in the family system (Danesphour, 2017).

According to Bowen, if one does not see oneself as part of a system, the person tries to change others or withdraws oneself. If one sees oneself as part of a system, the person maintains their communications with others and has alternative options such as self-change (Kerr \& Bowen, 1988). Ruptures definitely do not advocate differentiation much. For example, an unexpressed emotional rupture can appear when an adolescent appears anxiously silent toward the father's anger. The basic assumption of this theory advocates the importance of maintaining emotional contact with the previous generation, and this also helps decrease the emotional responses in existing relationships. In order to avoid emotional ruptures, maintaining emotional contact with previous generations is important. This assumption is very important for working with Muslim families because maintaining communications with previous generations is an expectation among Muslim families and a prerequisite for healthily maintaining interactions in large families. Beyond this, the family can experience intense emotional pressure when an emotional rupture occurs because handling the unresolved conflicts from the emotional break is avoided. In this case, triangulations create a path that family members can use for dealing with the emotional rupture by receiving support from others (Danesphour, 2017).

\section{The Process of Intergenerational Transfer}

The concept of the multi-generational transfer process emphasizes the transfer from generation to generation of the strategies and patterns used for coping with stress. The intergenerational transfer process or the multi-generational transfer process underlines the previous emotional processes of the family to maintain their existence in the emotional processes of the current family (Gehart, 2014). Children are the 
first object of the process of intergenerational transfer. The differentiation process of the parents plays an important role over the child's differentiation level (Nazl1, 2007). Methods for dealing with anxiety, such as the traditions that are transferred between generations, are also among the things passed down from generation to generation. When looking at this situation in terms of spirituality, this is also seen among the things passed down from generation to generation. How spirituality is used when coping with anxiety maintains its existence by passing from family to family (Danesphour, 2017).

\section{Siblings' Positions}

Family or background studies provide understanding of the place and roles of siblings within the family. This important therapeutic process helps identify how an individual's experiences with the role of sibling are positioned within the family relationship. The cultural and ethnic background of a family affects the value children give to gender and order of birth in the family. For example, the child's gender is the main factor in deciding whether that child's role will be relational (female) or task-oriented (male). The role of the eldest son carries great importance at home in Muslim families as the idea is common that the eldest boys will assume the family's economic responsibility. The position of the eldest daughter is important in the family in terms of taking care of household chores and finding solutions to the possible relational problems (Danesphour, 2017).

\section{The Family Reflection Process}

In the family reflection process, parents who can differentiate at a very low level reflect their own immature structures onto their children (Kerr \& Bowen, 1988). The reflection process happens among the mother-father-child triangle, and the transfer is done more against the child that is vulnerable. The main reason underlying the transfer being done to the vulnerable child is that the child is still unable to differentiate and is emotionally dependent on the family. The parents' different behaviors toward their children cause differentiations in the children's functions as well. The child who is most affected by the reflection process becomes too intertwined with the family and more vulnerable toward emotional stresses (Nazl1, 2007). The transfer process in the family takes place around the mother because she is the one who produces at home. The mother's anxiety initiates this process. The father has a more supportive role. The anxious parent behaves neurotically, guardedly, and irritably toward the child. As a result of this process, emotional destruction occurs in the child (Bowen, 1976).

Although having different intensity, the family reflection process like all of Bowen's concepts occurs in every family. This situation reflects more intensely in Muslim families, who expect family members to always be close to each other. 
Intergenerational dynamics can be effective in determining which child may develop symptoms or in which stage of the life cycle problems will emerge in the family. Family crises and the timing of crises can also affect some children's tendency to develop symptoms. According to Bowen, rather than being factors that create stress in the family, traumatic events are experiences that draw attention to the relational processes in the family (Danesphour, 2017).

\section{Societal Regression}

Societal regression is the seventh and final concept in Bowen Family Therapy. The most significant point in this concept is that society, like family, can create a force opposing individualization. An increase in the sense of togetherness occurs in social settings where chronic anxiety forms. Therefore, the perspective family members acquire related to how society functions gains importance (Goldenberg \& Goldenberg, 2008). A society can regress or it can advance. Increases in crime and violence, increasing divorce rates, economic imbalances/crises, polarizations among racial groups, natural disasters, and other traumas can be shown as symptoms of societal regression. In cases of societal regression, individuals tend to exhibit behavior that will reduce current worries rather than make long-term predictions. In other words, instead of making rational decisions, they make emotional decisions and apply them (Gladding, 2012).

Social progress is a process that occurs when problems are openly and clearly identified and described realistically instead of decisions being made on managing stress related to individuals, events, or situations. In the process of progress, scientific advancements are recorded and can be proven in the light of scientific data; decisions are made based on logic supported by facts. Many Muslim states struggle with leaders who are part of a corrupt government system. The rest also have been exposed to wars that endanger even their daily lives, ethnic discrimination, or disruptive economic policies. Therefore, family therapies should also consider these circumstances that affect the sociopolitical conditions and daily functions of the society where these families live when making evaluations while working with Muslim families (Danesphour, 2017).

\section{The Role of The Therapist in Bowen Family Systems Theory}

In the Bowen Therapy process, clients' relationships with others are emphasized more than their relationship with the therapist or investigating clients' inner thoughts about themself (Bowen, 1978). The therapist does not have the position of a specialist or guide toward the client; on the contrary, the therapist is equal to the client. Unlike other psychological counseling approaches, here the association of the therapist and the client is less emphasized. For this reason, practices that overemphasize the 
therapist-client relationship and give weight to this relationship in the process are considered harmful to the Bowen therapeutic process (Bowen, 1978).

The therapist's primary purpose regarding the process in spiritually oriented Bowen Family Therapy is to assist the client in gaining differentiation of self or in reaching emotional maturity. This process includes establishing a balance between clients' thoughts and feelings and recognizing the possibility for clients to experience their own individuality while establishing emotional bonds with the important people in their lives. Self differentiation and anxiety are two concepts with different dimensions; consequently, high levels of self-differentiation provide decreased chronic anxiety. Reducing anxiety goes hand in hand with the symptoms decreasing. In the therapy process, the consultant benefits from simple principles for determining the client's relationships with others. In order to do this, systematic parts are determined and the client's position in the family is clearly defined. In the process, clients gain their own perspective and direct their decisions. The therapist does not determine the extent of the client's relationship with God, clients themselves do this. Therapists always preserve their neutrality so clients can guide their own relationships. Therapists should be careful on the topic of describing their own personal beliefs and relationship with God (Jensen \& Mid, 2003).

\section{Bowen Family Systems Therapy in Muslim Families}

Bowen Family Systems Theory has a special place in working with Muslim couples and families. From Bowen's point of view, determining and trying to make sense of couples' dysfunctional patterns of behavior is essential (Sauerheber et al., 2014). Bowen Family System Theory also includes practices with religious and spiritual dimensions by nature of its structure. Addressing the subject from the view that the Islamic world looks at marriage and couples' relationships is important from this perspective.

Islam is a great religion that finds itself in a wide range of geographies. Despite Islam being a very widespread religion, studies addressing Muslim families and Islam within family systems are quite limited. Existing and future studies as well are shaped by the explanations Islam makes regarding marriage and family life (Springer et al., 2009). For family therapies to be applied in Muslim families, therapists must be familiar with the beliefs, traditions, customs, and needs in the Muslim marriage system (Sauerheber et al., 2014).

The first sessions in many couples therapy are performed more toward understanding how the couples met and how they got married. In traditional Islamic culture, the family's approval and support in the choice of spouse is very important, unlike Western societies. Muslim couples both see marriage as a moral safeguard 
and look at marriage with the eye of a sacred contract that will provide them with a peaceful environment (Asamarai et al., 2006). Muslim couples with similar levels of faith have common perspectives on what Islam expects from married couples and what the couples expect from each other as husband and wife (Sauerheber et al., 2014). According to Bowen (1966), individuals who have similar values and differentiation levels become couples; when looked at from this perspective, similar religious faith, an similar beliefs, sect, and spirituality for Islam can be included within these similarities.

On the topic of spousal relations in Islam, the Qur'an (30:21) has the following to say, "And among His Signs is this: that He created for you wives from among yourselves, that you may find repose in them, and He has put between you affection and mercy." What is expected of couples here is not that they should just be individuals who form the institution of marriage but that they also should be connected to one another with love and compassion. In addition to what the Qur'an has to say, couples need to have an idea about their own spiritual leaders' perspective and views related to marriage and relationships (Abdal-1 Ati, 1974).

The majority of Muslim couples have similar perspectives to one another; conversely, however, couples also exist who have different perspectives on life, who experience various conflicts, and who have differences of opinion. Couples who experience such problems in their marriage are unable to gather the necessary courage about getting psychological support and should be encouraged on the topic of receiving professional psychological support. In Islamic understanding, intervening third parties (parents, relatives) generally attempt to reconcile couples who are experiencing problems (Springer et al., 2009). According to Altarebe (2008), In these cases appointing an arbitrator is needed. In traditional Islamic culture, however, this arbitrator is not a therapist specialized in this task; generally it is someone in the immediate vicinity of the couple. One of the main reasons for this is considered to be that the couple doesn't want to bring out the problem they're experiencing in the marriage and having someone external hear these types of problems is embarrassing (Daresphour, 2009).

In Islamic understanding, the case of appointing an arbitrator for solving family problems is a door opener for the couple to get help from a family therapist. Bowen Family System Theory attempts to understand the dynamics of the family systems dynamics just like an arbitrator without taking sides in a way that is harmonious with Islamic understanding. A therapist possessing the Bowen perspective attempts to understand the anxiety originating from the family structure that emerges because of opposite poles within the family (Sauerheber et al., 2014).

As described above, Bowen Family Theory is an approach with a spiritual dimension that evaluates the family by addressing them as a whole within the system 
the couple is found. Bowen's basic concepts are benefitted from in the process of Bowen Family Therapy in evaluating the couple and determining the intervention techniques. Below is found a case study that has been addressed according to the Bowen Family Systems Theory (For a detailed description of the case, please see Sauerheber [2013]).

\begin{abstract}
The Case of Aahil and Omera
Aahil, 31, and Omera, 30, are a couple who've been married for 2 years and who had dated for 1 year before getting married. The pair met during college when they were in the same study group in philosophy class. While in the study group, they noticed how much they have in common and decided to be together. The two come from religious families and they have good relations with their families. Aahil's family lived in the same city as him during the university period. Aahil's father's father had emigrated from the Middle East when the kids were very young. The mother's father had come and settled in America when the mother was very little. Since migrating, all family members have lived in the same city and frequently visit one another.

Omera's family lives about 200 miles away. While Omera was in college, she stayed in the same city with her uncle and two aunts. The elders from both Omer's mother's and father's side had settled in the city where they live while his mother and father were very little. Omera's family does not have close relations with relatives outside of her immediate family.

Aahil's greatest dream is to start his own business like his father and in this way provide job opportunities to all his relatives near and far. Aahil had completed his university education both to take over his father's jobs and to have a second choice for himself. Aahil's mother is a housewife and quite satisfied with this situation. Aahil feels very fortunate to have such a mother who is always interested in her children. Omera's father is a family doctor. Despite earning money to support his family, he constantly supports his wife's dream of becoming an artist. While the children were in primary school, he even opened an art studio for her. Omera feels proud of her mother and father.
\end{abstract}

A conflict broke out between the couple when Omera wanted to continue on to her doctorate education in the field of sociology. Aahil thought this would be a negative situation for having children in the future and that this education would interrupt his plan to have children; he wants to continue his lineage. He thought that, because all of his siblings have children, hanging up this idea himself would disappoint his dad. Although he appreciates Omera, he stated no longer being loved by or feeling respect from her, and thus he feels angry at Omera anymore. If Omera persists, he emphasized that they will sin. He thinks Omera is safer at home. His family, especially his older brother Mihyar, had shared with Omera their thoughts on the difficult situation their families were left in when faced with Omera's behaviors, which were the same as Aahil's; this had caused the problem to escalate. Mihyar looks at events from the traditional Islamic perspective; although Omera understands this, she got angry at her husband for taking his brother's sides. Additionally, Omera wants children too, but her education plans caused her to delay this situation; Omera's family supports her. By thinking about how strong and free she had been before marriage, her anger toward Aahil increased more. Omera in fact loves her husband and is happy with him; however, because he has no idea about the things that can make her happy and is constantly selfishly looking after his own needs, she's experiencing problems with her husband. Also, her sister-in-law's constant comments on their marriage and involvement in their relationship angers Omera, and this stirs up her anger toward Aahil. Aahil gives examples of scripture defending that his own needs come before that of his wife, and this has put the relationship in a deadlock.

The Therapy Process: While approaching this couple, a Bowen therapist takes into account a few assumptions on their arrival to therapy. The therapist assumes the couple is having a conflict they cannot solve, they have an emotional distance that creates problems between the spouses, one spouse's emotional functions are noticeable broken, and one or more children that the couple have create anxiety in the couple's relationship (Kerr \& Bowen, 1988). The process moves ahead by addressing the sub-dimensions of the theory one by one in the process. The analysis of Omera and Aahil's case takes place below under the following headings.

Nuclear Family Emotional System: Aahil is quite attached emotionally to his family, even integral to them. Even though this situation complies with cultural expectations, it can create problems between the couple because it affects Aahil's behaviors and creates obligations. Getting his family's approval is very important to him. Aahil shows more devotion to Islamic traditions and pays a lot of attention to close family relationships, as the religious perspective requires. Aahil both wants to make Omera's dream come true as well as fears her gaining independence from this situation. If Aahil had been emotionally attached to Omera he wouldn't have intervened so much in Omera's life. This situation harms the couple's relationship. 


\section{The Case of Aahil and Omera}

Self Differentiation: Omera differentiates quite well from her family. Her father's clear, accepting, and supportive attitudes have had a great impact on this situation. Aahil lives through the expectations of his family instead of his own life, and this also creates problems in the couple's relationship. Unlike in Omera's family, individualism and independence are not things encouraged in Aahil's. Aahil gives value to his family's views on marriage and continues his life in a way that is dependent on his family.

In Bowen, the idea is prevalent that individuals with similar levels of differentiation come together. Although Omera and Aahil seem to have nothing in common here, when considering when they met and got married, the facts that they were both students, have close relationships with their family, have the same religious beliefs, and are dependent on these religious beliefs can be addressed as the factors that brought them together.

Triangulations: More than one person has formed triangulations in the case of Aahil and Omera. Although
Aahil's father is not directly involved in the relationship, he is a third person in relation to the recommendations
he gives his son. The most apparent triangle is Mihyar, because Aahil is very impacted by his suggestions. As
a family member who intensely bears the Islamic traditionalist perspective, Mihyar evaluates events through
the window of religion and conveys these indoctrinations to his brother. Because Omera does not have a very
intense Islamic tradition despite being a Muslim and a believing person, she has difficulty understanding
Mihyar, and here Mihyar emerges as a third person who brings the relationship to a dysfunctional state.

Emotional Ruptures: When looking at this situation in terms of Aahil and Omera, because Aahil differentiates less than Omera, the experienced emotional situations and their results appear. Aahil continues to be on the side of his older brother, Mihyar. The fact that Aahil continues to hold onto the traditions from his family has not led to positive emotions for a Muslim spouse. When Omera forces Aahil to make a choice, Aahil gets stuck in the middle, and this case causes him to distance himself emotionally and behaviorally from Omera. When looked at from Omera's perspective, Omera will be unhappy if she accepts this situation. Here Omera is also able to take the views of her own family. The decisions Omera will give will also be related to the marriage.

Intergenerational Transfer Process: When considering how this principle applies to this case, a genogram for Aahil and Omera's family can be drawn. Instead of emphasizing family roles, careers, illnesses, birthdays, divorce histories, marriages, and separations, this genogram will focus on family members' emotional ties an interactions. How does Omera describe her emotional relationship with her mother and father? How does she express this? How is she allowed to communicate her love? Was she able to feel that her mother and father are people who are close, love each other, and respect one another even in difficult situations? In addition, was she able to feel safe in the relationships she established with family members while trying to realize her own goals and dreams? If she hasn't experienced an increased fear, concern, or insecurity, she is likely able to differentiate from her family members. Most of her family members are likely to experience this level of differentiation. When the concept of differentiation carries a relative and compulsory quantitative weight, deciding on Aahil's level of differentiation becomes important. Alongside this, Bowen theory draws a map for us to understand relational behaviors, or it provides a language of communication where we can make sense of this. We can conclude here that Aahil's differentiation from his father and mother is less than that of Omera's: Aahil (a) feels quite anxious about how his family will perceive him; (b) makes decisions based on how the others will react; (c) feels fear and anxiety in his relationships with family members, especially when he doesn't meet the expectations he thinks they believe in, and (d) feels threatened and therefore feels anxious in regard to Omera's desire to reach her personal goals. The genogram can be used to show Aahil's triangulation patterns with his family and to recognize the family members who manage to avoid triangulation.

\section{Results}

Bowen Family Systems Theory is an approach with many dimensions and a clinical infrastructure. Bowen Family Theory addresses the family as a systems and attempts to analyze individuals' problems by considering the environment in which they are found. This environment houses many states, from family to culture, from siblings to religious beliefs, and from traditions to customs.

Some key concepts exist in Bowen Family Systems Theory, these being differentiation of self and triangulations. Differentiation of self is both the individual distinguishing the self from others emotionally and behaviorally as well as being aware 
of the distinction of one's own thoughts and feelings. The level of differentiation is also encountered in individual-God relationships. According to Bowen, spirituality is the topic of God being reflected in relationships. With respect to this, God and spirituality being taught in dissimilar ways can assist in analyzing the systems located within the family. Triangulations are the involvement of third parties or situations in a relationship in the case of a possible problem situation or in the routine course of the relationship. This third party can also emerge as the God where the beliefs of people originate from.

Because of the prospect of being able to include religion, beliefs, and spirituality in the process, which is multi-systematic in the Bowen approach, spirituality is an approach we can easily integrate. Due to intertwined an interconnected family dynamics, Bowen therapy is an important model that can be used for working with spiritual and religious families; the degree of anxiety and worry and the level of family differentiation can be evaluated here, and appropriate interventions can be used in line with this.

Looking at this approach addressing all the systems around the family together from the window of spirituality as a significant family value is important. Bowen theory 1s a comprehensive approach that also hosts spiritual and religious elements within it. Studies in the literature that look from the perspective of the Bowen approach are strikingly limited. From this angle, addressing the issue from the perspective of its religious and spiritual characteristics is important. This study, which has been done for the purpose of addressing the spiritual and religious dimensions of the Bowen approach, is considered to fill the gap existing in the literature related to this topic and to contribute to future research.

\section{Acknowledgement}

This article does not involve any human participant data, and thus no ethical approval was required.

\section{References}

Abdal-Ati, H. (1974). Modern problems, classical solutions: An Islamic perspective on the family. Journal of Comparative Family Studies, 5, 37-54

Acar, T., \& Voltan-Acar, N. (2013). "Babam ve Oğlum” filminin çok kuşaklı /kuşaklararası aile terapisi' nin temel kavramları açısından değerlendirilmesi. Kuram ve Uygulamada Eğitim Bilimleri, 13(1), 37-53.

Altarebe, B. (2008). The practice of marriage and family counseling and Islam. In J. Duba Onedera (Ed.), The role of religion in marriage and family counseling (pp. 89-104). New York, NY: Routledge/Taylor \& Francis Group.

Asamarai, L. A., Solberg, K. B., \& Solon, P. C. (2006). The role of religiosity in Muslim spouse selection and its influence on marital satisfaction. Journal of Muslim Mental Health, 3, 37-52. 
Batson, C. D., \& Ventis, L. (1982). The religious experience: A social-psychological perspective. New York, NY: Oxford University Press.

Berensen, D. (1990). A systematic view of spirituality: God and twelve step programs as resources in family therapy. Journal of Strategic and Systematic Therapies, 9, 59-70.

Bowen, M. (1966). The use of family theory in clinical practice. Comprehensive Psychiatry, 7, $345-374$

Bowen, M. (1978). Theory in the practice of psychotherapy. In P. J. Guerin (Ed.), Family therapy: Theory and practice (pp. 42-90).New York, NY: Gardner Press.

Bowen, M. (1985). Family therapy in clinical practice. New York, NY: Jason Aronson

Burris, C., Jackson, L., Tarpley, W. R., \& Smith, G. (1996). Religion as quest: The self-directed pursuit of meaning. Personality and Social Psychological Bulletin, 22, 1068-1076.

Butler, M. H., \& Harper, J. M. (1994). The divine triangle: God in the marital system of religious couples. Family Process, 33(3), 277-286. doi: 10.1111/j.1545-5300.1994.00277

Butler, M. H., Stout, J. A., \& Gardner, B. C. (2002). Prayer as a conflict resolution ritual: Clinical implications of religious couples' report of relationship softening, healing perspective, and change responsibility. American Journal of Family Therapy, 30, 19-37.

Corey, G. (2008). PPsikolojik danışma ve psikoterapi kuram ve uygulamaları. (çev. T. Ergene). Ankara: Metis Yayınc1lık.

Daneshpour, M. (2017). Couple therapy with Muslims: Challenges and opportunities. In M. Rastogi \& T. Volker (Eds.), Multicultural Therapy (pp. 103-120). Thousand Oaks, CA: Sage.

Gehart, D. (2014). Matering compentencies in family therapy a practical approach to theories and clinical case documentation. Belmont: Brooks/Cole Cengage Learning.

Genia, V. (1996). Quest and fundamentalism as predictors of psychological and spiritual wellbeing. Journal for the Scientific Study of Religion, 35, 56-64.

Gladding, S. T. (2012). aile terapisi, tarihi, kuram ve uygulamaları. (çev. İ. Yıldırım ve İ. Keklik). Ankara: Türk Psikolojik Danışma ve Rehberlik Derneği.

Goldenberg, H. ve Goldenberg, I. (2008). Family therapy an overview. Belmont: Thomson Hieger Education.

Jankowski, P., \& Vaughn, M. (2009). Differentiation of self and spirituality: Empirical Explorations, Counseling and Values, 53, 82-96.

Jensen, C. A., \& Min, D. (2003). Toward pastoral counseling 1ntegration: One Bowen oriented approach. The Journal of Pastoral Care, 55, 1.

Kerr, M. E., \& Bowen, M. (1988). Family evaluation: An approach based on Bowen theory. New York, NY: W. W. Norton\&Company.

Kesici, Ş., Bayrakcı, K. E., Mert, A., \& Kiper, C. (2014). Vaka örnekleriyle birlikte aile danışma kuramları ve teknikleri. Ankara: Nobel Akademik Yayıncılık.

Klever, P. (2009). Goal direction and effectiveness, emotional maturity, and nuclear family functioning. Journal of Marital and Family Therapy, 35(3), 308-324.

Koenig, H. G., King, D. E., \& Carson, V. B. (2012). Handbook of religion and health. New York: Oxford University Press.

Mert, A., \& Topal, T. (2018). Benlik ayrımlaşmasının manevi yönelimine etkisinin bazı değişkenlerle incelenmesi. OPUS-Uluslararası Toplum Araştırmaları Dergisi, 8(14), 68-91. doi: 10.26466/ opus.393261. 
Minuchin, S. (1981). Family Therapy Techniques. Cambridge, MA: Harvard University Press.

Nazlı, S. (2007). Aile danışmanlı̆̆ı. Ankara: Anı Yayıncılık.

Polat, K. (2014). Evli bireylerde çift uyumu ve bazı psikolojik belirtilerin benliğin farklılaşması açısından incelenmesi. Yayınlanmamış Yüksek Lisans Tezi. Gaziosmanpaşa Üniversitesi, Tokat.

Sauerheber, J. D., Nims, D., \& Carter, D. J. (2014). Counseling Muslim couples from a Bowen family systems perspective. The Family Journal: Counseling and Therapy for Couples and Families, 22(2), 231-239.

Sheen, F. J. (2004). Three to get married. Princeton, NJ: Scepter.

Springer, P. R., Abbott, D. A., \& Reisbig, A. M. J. (2009). Therapy with Muslim couples and families: Basic guidelines for effective practice. The Family Journal: Counseling and Therapy for Couples and Families, 17, 229-235.

Rizkallah, N., \& Hudson, E. (2019). Circling the Triangle: An EFT Approach to working with Christian couples triangulating God. Contemporary Family Therapy, 41, 219-226. doi: 10.1007/ s10591-019-09496-8.

Rootes, K. M., Jankowski, P. J., \& Sandage, J. A. (2002). Bowen family systems theory and spirituality: Exploring the relationship between triangulation and religious questing. Contemporary Family Therapy.

Titelman, P. (2003). Emotional cutoff: Bowen family systems theory perspectives. New York: NY Haworth.

Varol, R. (2015). Genogram temelli yürütülen psikolojik danışma sürecinin çiftlerde evlilik uyumu, duygusal bağlllık, evlilikte problem çözme ve benliğin ayrımlaşma düzeylerine etkisi. Yayımlanmamış Yüksek Lisans Tezi. Mevlana Üniversitesi, Sosyal Bilimler Enstitüsü.

Young, J., Wiggings-Frame, M. ve Cashwell, C. (2007). Spirituality and counselor competence: A national survey of American Counseling Association members. Journal of Counseling and Development, 85, 47-52.

Zinnbauer, B. J., \& Pargament, K. I. (2013). Dindarlık ve maneviyat. (Çev. Sevde Düzgüner). R. F. Paloutzian \& C. L. Park (Ed.). Din ve Maneviyat Psikolojisi (pp. 6-102). Ankara: Phoneix Yayınevi. 